\title{
SAGRADO, PROFANO, PÚBLICO E PRIVADO: DIMENSÕES DAS POLÍTICAS PÚBLICAS DE "EVANGELIZAÇÃO" DO GOVERNO DO ESTADO DO RIO DE JANEIRO*
}

\section{Fernando de Castro Fontainha}

Advogado, membro do grupo de pesquisas "Direito, Tecnologia e Sociedade", mestrando em Sociologia e Direito pela Universidade Federal Fluminense, bolsista Capes.

\section{Pedro Heitor de Barros Geraldo}

Professor Substituto da Faculdade de Direito da Universidade Federal de Juiz de Fora, membro do grupo de pesquisas "Direito, Tecnologia e Sociedade", mestrando em Sociologia e Direito pela Universidade Federal Fluminense, bolsista Capes.

RESUMO: O fenômeno religioso no Brasil, especialmente aquele de orientação pentecostal, tem sido estudado em diversos matizes. Tudo fica ainda mais complicado quando fazemos a interface entre esse novel campo religioso com o tradicional campo político. Neste trabalho, estudamos duas propostas específicas de políticas públicas do Governo do Estado do Rio de Janeiro: "conversão" de homossexuais e adoção do criacionismo no ensino público fundamental. A problemática se torna relativa ao tema no tocante aos atores envolvidos. Tanto a governadora Rosinha Garotinho, como seu marido, o ex-governador Anthony Garotinho, credenciam-se publicamente como fiéis da denominação pentecostal "Assembléia de Deus". O trabalho se pretende à formulação de uma hipótese: a de que está ocorrendo uma sacralização do espaço público e, paralelamente uma laicização da religião. Isto porque, se por um lado, a reinterpretação do espaço público passou a se dar a partir dos referenciais de uma visão sacralizada do mundo, em contrapartida, o estado de pertença religiosa tem sido o ponto de partida para o amálgama de relações interpessoais formadoras de um "patrimônio organizacional", de natureza eminentemente "profana", ou seja, da vida material. Nesta perspectiva, é necessário o cotejo de duas concepções de cidadania: uma universalizante, própria de um espaço público laico, e outra fragmentária, peculiar a um espaço público pluralista, onde se embatem diversas identidades.

PALAVRAS-CHAVE: Cidadania e identidade; Privatização do espaço público; Laicização dos fenômenos religiosos; Sociologia da religião; Sociologia da política.

*O presente artigo é um dos frutos do Acordo Capes/Cofecub n..$^{469 / 04}$, celebrado entre a Universidade Federal Fluminense e a Université de Montpellier I, coordenado pelos professores Roberto Fragale e Michel Miaille, com título "Identidades regionais e cidadanias". 


\section{INTRODUÇÃO}

Este trabalho versa sobre a análise das propostas de políticas públicas adotadas pelo Estado do Rio de Janeiro, quais sejam a adoção do criacionismo no ensino público estadual e a conversão de homossexuais.

Brevemente, deve-se recordar que Rosinha Garotinho é esposa de Anthony Garotinho, ex-governador do Estado do Rio de Janeiro. O casal declaradamente pertence à Igreja Presbiteriana, denominação que reúne $11,5 \%$ dos evangélicos de missão, situando-se em quarto entre todas elas, de acordo com os dados do último censo nacional realizado pelo IBGE.

Deste modo, sustentar-se-á que existe uma tendência em procurar legitimar a autoridade religiosa dentro do espaço institucional, materializando a disputa do capital religioso através destas políticas públicas. Objetiva-se, assim, demonstrar que o espaço público vem sendo progressivamente colonizado por uma visão de mundo que não Ihe tem sido peculiar: o sagrado.

Isto por si só não desabona os fins almejados, mas por que tais pretensões redimensionam o espaço público de modo a recaracterizar a cidadania, pelo menos no que toca aos fiéis contemplados por tais políticas. Para tanto, o discurso religioso se transmuta em político para servir de esteio a tais políticas.

As relações entre religião e política analisadas aqui serão compreendidas através de dois eixos: cidadania e identidade. O primeiro concerne a dimensão pública e a inserção social dos fiéis, estes, por sua vez, se destacam dentro do domínio público pelo estado de pertença religiosa que os caracteriza. Em outras palavras, afirmar-se evangélico, significa postular e defender determinados interesses comuns a tal grupo que somente são reconhecidos em virtude da ascendência social da mesma.

\section{O PÚBLICO E O PRIVADO: CIDADANIA E IDENTIDADE}

Perquirir sobre a identidade dentro de determinada sociedade equivale a buscar a homogeneidade dentro da diversidade. A idéia de um estado de pertença se refere a esta identidade comum a um grupo social que disputa maior inserção na esfera pública. 
Todavia mesmo esta homogeneidade não se estriba no consenso sobre as diretrizes ou finalidades da ação coletiva, no interior do grupo há facções em disputa pela sua liderança. Esta percepção agonística da identidade na qual o indivíduo se sobressai em razão dos próprios méritos remete à idéia do espaço público não como um ambiente destinado à paz e à harmonia social, pelo contrário,é o devido lugar do conflito e das disputas. Hannah Arendt, retomando a construção da ágora, afirma que ela "era reservada à individualidade; era o único lugar em que os homens podiam mostrar quem realmente e inconfundivelmente eram" [pp. 51]. Sob este ponto de vista, a sociedade não se torna apenas um emaranhado de interesses contrapostos, ao invés disto sua organização é tributária das disputas que são sediadas em cada grupo e na ágora - entre eles.

Decorre daí que o discurso autônomo de um grupo constrói-se a partir da luta pela liderança, não há por que considerar, portanto, um viés essencialista da concepção de religião - que é o caso deste trabalho -, isto é, os evangélicos, mas um produto das forças sociais que a criaram. Desnaturalizá-lo contribui para a percepção de que o discurso religioso pode ser traduzido em discurso político, se assim quiserem os líderes ou a força inexorável da conjuntura.

Esta postura metodológica lançada para a apreensão do objeto é capaz de compreender as estruturas (se é que elas existem!) do campo religioso e político como artefatos humanos e não como algo pronto e acabado. $O$ discurso, embora perpasse pela substancialidade - algo que está fora dos homens e da sociedade -, deve ser entendido como uma construção derivada do embate das relações de grupo e das inter-relações entre membros de cada grupo.

O crescimento das igrejas pentecostais não ocorreu por acaso, ou pela providência divina, mas, sobretudo, pela demanda por tal discurso. A retórica pentecostal segue uma dinâmica de sacralização do mundo, ou seja, as instituições e os conflitos sociais são necessariamente naturalizados a fim de que a religião possa prover uma boa explicação para a compreensão da organização deste mundo. O fiel não estranha as condições em que vive mas as percebe como produções divinas, algo que the foi dado e é impassível de ser modificado por sua condição humana.

Para os evangélicos, há um dado peculiar, qual seja o fato de que não é uma confissão de culpa. Isto significa que o mundo estrutura-se entre o sagrado (a 
presença da divindade) e o profano (a vida mundana), assim sendo, ser fiel é estar próximo de deus e afastado do diabo, independente da vida mundana. Aquilo que é repudiável pelo grupo está com o diabo ao passo que aquilo que é tolerado está com deus, pois suas experiências cognitivas são reinterpretadas segundo quadros de referência presentes numa visão de mundo orientada pelo sagrado. Carlos Rodrigues Brandão explicita esta configuração identitária dos fiéis da Assembléia de Deus nesta longa passagem que vale ser citada na íntegra:

"O evangélico e, especialmente, o pentecostal delimitam os domínios absolutamente opostos entre o sagrado e o profano e diferenciam o universo religioso brasileiro com uma força de detalhes cujo o exame, melhor do que entre católicos e mediúnicos, ajuda a compreender a construção das relações que a identidade denomina e qualifica. De um campo do que é socialmente reconhecido como real, existente fora da pura e simples imaginação, ele recorta em primeiro lugar uma dimensão de sagrado, oposta a uma dimensão terrena do profano. De um lado coloca o sub e o sobrenatural, o celeste e o demoníaco, e, do outro, aquilo que é profano porque é "do mundo", em uma visão inicial que depois modificará. Se, de um lado, o profano é todo o campo de sujeitos, situações e símbolos que não são e não podem ser diretamente associados ao que existe fora do mundo material, de outro lado a dimensão demoníaca do sagrado profana o religioso e estabelecerá uma segunda qualificação da idéia de "ser do mundo", ou seja, ser o oposto ao sagrado celeste. Assim, um ateu ou um maçom estão "no mundo" porque não são sujeitos de religião e, portanto, são a afirmação social da possibilidade do profano. Mas um umbandista ou um espírita, percebidos pelo evangélico como identidades que lidam com o sagrado, são profanadores da religião pelo fato de que fazem a opção pelo culto de forças que, não-terrenas, são igualmente não-celestiais. Não são "de Deus" e, por isso mesmo, só podem provir do "mal", do "demônio", da "feitiçaria" (sempre associada entre os pentecostais como forma cultural de realização do demoníaco)" [pp. 34].

Nesta concepção o mundo se explica em sua totalidade através das categorias evangélicas. Porém este ponto de vista destinado à privacidade, ao indivíduo, adquire uma dimensão pública ao produzir regularidades na ação social deste grupo e, principalmente, fundamentar políticas estatais. O governante religioso neste caso Rosinha Garotinho - transfere a mesma percepção do mundo para a governança.

Sua atividade (estar-no-mundo) é pautada pelos valores de sua crença religiosa, a lógica de entendimento do mundo é a mesma. Ora, como evangélica ela deve estar longe das entidades demoníacas e afastá-las das pessoas, portanto 
como governante sua militância religiosa é um empreendimento sofisticado que usa a seu serviço o aparato do Estado para manter os indivíduos/cidadãos próximos de deus. Afastando por completo a visão de mundo profana dos seus atos políticos.

A lógica do público/privado modifica-se completamente, ela não desaparece de maneira que um ascende sobre o outro, mas parece que a religião deixou de ser algo a ser experimentado no espaço privado e ganhou contornos públicos, já que a lógica do governador/profeta se materializa em políticas públicas.

Embora pareça haver uma tolerância religiosa na sociedade brasileira, devido a multiplicidade de crenças religiosas, isto não quer dizer que as religiões sejam mais tolerantes. Da citação acima, o autor aduz que ateus e maçons são a comprovação da existência do profano, assim como o homossexualismo o é conforme dados da tabela abaixo.

Distribuição dos evangélicos segundo a posição sobre o homossexualismo masculino*

\begin{tabular}{|l|c|c|}
\hline Denominação & Escolha sexual é livre (\%) & Imoralidade ou doença (\%) \\
\hline Assembléia & 10.3 & 89.7 \\
\hline Congregação & 23.8 & 76.2 \\
\hline Universal & 45.4 & 54.5 \\
\hline Outras pentecostais & 12.5 & 87.5 \\
\hline Batista & 21.0 & 78.9 \\
\hline Outras não-pentecostais & 26.3 & 73.7 \\
\hline Não especificou denominação & 16.7 & 83.3 \\
\hline
\end{tabular}

${ }^{\star}$ Nivel de significância de 0.000 no teste de qui-quadrado (valor de 29.9559); V de Cramér: 0.1587. Fonte: ESEB 2002

Isto demonstra através da política de conversão de homossexuais que 0 Estado não passa a gerenciar cidadão, mas indivíduos a serem salvos. Ser salvo no caso exprime a laicização dos conflitos entre religião e política no Brasil. Carlos Brandão expõe que:

“Uma pessoa 'crente' é, antes de tudo, a pessoa de um crente, e todos os outros qualificadores de sua identidade - o local de origem no país, o grau de instrução escolar, a profissão atual, a definição política - são secundários, ou são reescritos a partir da maneira como o sujeito pentecostal submete todas as dimensões de sua ação social e da representação que faz de si, através de tal ação significativa, aos termos e símbolos de sua identidade militantemente religiosa" [pp. 36] (grifos nossos).

Toda a vida pregressa é abandonada. Não é possível fazer uma autocrítica da vida passada, já que o ritual de conversão a transforma em outra pessoa. Deste 
modo, a crítica é atribuída não a ela mesma, mas a uma pessoa que deixou de existir que se transformou em outra totalmente diferente: uma "nova criatura".

A homogeneização através da conversão faz dos fiéis militantes assíduos que percebem o mundo através de suas categorias de compreensão (sagrado e profano). É esta militância que atinge a esfera pública, porém quando toca o espaço institucional do Estado o móvel da ação não pode ser mais a religião, que, embora adquira dimensão pública, jamais será passível de revisão por aqueles que não professam a mesma religião ou que sejam ateus.

\section{O ESTADO DE PERTENÇA RELIGIOSA COMO PATRIMÔNIO ORGANIZACIONAL: MOBILIZAÇÃO DE CAPITAL IDENTITÁRIO E EMPREENDEDORISMO POLÍTICO (A TEODISSÉIA DA POLÍTICA)}

Max Weber fazia uma longa viagem por um antigo território indígena nos Estados Unidos dividindo apartamento com um viajante que comerciava inscrições de ferro para sepulturas. Certo dia, enquanto assuntavam, o comerciante lhe fez a seguinte afirmação: "Senhor, por mim cada qual pode crer ou não crer no que melhor the pareça: mas quando vejo um agricultor ou um comerciante que não pertence a nenhuma igreja, pra mim esse homem não vale meio dólar. Porque ele me pagaria, se não crê em nada?" [1992a, pp. 205]. Em outra ocasião, assistia com um parente a uma cerimônia de batismo coletivo em Bunchwald, perto da capital da Carolina do Norte. Seu parente, ao ver batizado um dos jovens, comentou: "Olha ele - Eu te disse!" Quando indagado por Weber sobre o que adivinhara, respondeu: "Porque quer abrir um banco na cidade? Com tantos batistas nas redondezas, como pode viver disto? Não pode, senão pelo batismo terá toda a comunidade como cliente, e os outros não Ihe poderão fazer concorrência" [idem. pp. 206].

$\mathrm{Na}$ descrição destas duas situações Weber chega a duas conclusões fundamentais acerca do impacto da modernidade sobre o fenômeno religioso: (i) a secularização (ou laicização) das concepções religiosas e a decorrente (ii) criação de um sem-número de seitas promotoras de relações interpessoais de solidariedade baseadas no estado de pertença [Idem. pp. 207-9]. Jamais se poderia imaginar que o estado de pertença religiosa poderia afetar o espectro de relações da pessoa para

\footnotetext{
${ }^{1}$ Quadro retirado do artigo de Simone R. Bohn.
} 
além de sua circunscrição confessional. O acesso ao crédito, à clientela, e, mais amplamente, a um garantido rol de prestações e contra-prestações devidas entre os membros. Uma verdadeira rede de relações interpessoais, uma relação de atribuição pela identidade, é o que chamaremos aqui de patrimônio organizacional.

Aqui nos interessa particularmente este tipo de atribuição em relação ao sistema político brasileiro. A relação que historicamente mantém os políticos profissionais com a sociedade civil brasileira tem a marca do fisiologismo, do paternalismo e do coronelismo. É aterradora a descrição dos sufrágios brasileiros do século XIX até as primeiras décadas do século XX feita por José Murilo de Carvalho. Muito embora realizadas em igrejas - que escondiam as imagens de santos para que não servissem de projéteis - era a intimidação moral e a violência física que por fim decidiam os processos eleitorais. Algumas especialidades de políticos profissionais (porque pagos) surgiram, especializados exclusivamente em burlar as eleições. O "cabalista" garantia o voto de todos na lista, inclusive forjando provas de suas condições legais para o exercício do voto. O "fósforo" substituía algum votante em caso de ausência ou morte. E o "capanga eleitoral" era quem garantia fisicamente a fraude ou que impedia fisicamente a fraude alheia (de outro grupo político) [pp. 33-4].

Nosso sistema político ainda é marcado profundamente pelo abismo que mantém com a sociedade civil. Esta, por sua vez, ainda não adquiriu maturidade organizativa suficiente para a produção de seus próprios porta-vozes. Maria Alice Rezende de Carvalho identifica tal fenômeno à partir dos índices - embora progressivos nas últimas décadas - irrisórios do patrimônio organizacional de nossa sociedade [pp. 323]. Ou seja, conclui a autora pela imensa precariedade das redes sociais mais ou menos institucionalizadas, indicativas de um baixo grau de confiança interpessoal na nossa sociedade. É evidente que não poderíamos deixar de mencionar que se deve adicionar ao diagnóstico apresentado sua potencialização pelo estado de desagregação funcional imposto pela reestruturação produtiva da especialização flexível, elemento essencial do que se convencionou chamar "pósmodernidade".

$\mathrm{Na}$ nossa tradição política, é comum a relação impessoal - porém assistencial - nas relações de atribuição pela política. O voto localizado ou regionalizado não implica na comunhão da identidade do local ou região. Um mineiro 
não vota em outro pela comunhão de valores culturais de Minas Gerais, mas por crer que o candidato lá focará seus esforços na melhoria de condições do local. A radicalização deste ponto de vista consiste nas práticas comuns de inclusão de famílias carentes em programas estatais de assistência às vésperas de eleição, distribuição de presentes ou mesmo a compra direta de votos.

Praticamente não há no Brasil quem não venda seu voto, de forma direta ou indireta, motivado pela confiança interpessoal que deposita em determinado candidato, uma vez que legítimo representante de seus valores. Este ambiente permite o surgimento de um tipo social que hoje se torna muito comum: o boss. $\mathrm{Na}$ proposta tipológica de Weber, o boss é aquele cujo capital manuseado é um certo número de votos, com os quais se autoriza e transforma na sua mercadoria, no seu sustento, no elemento de troca [1999. pp. 1089]. O boss não guarda qualquer laço ideológico claro com seu empregador. Em termos gerais, negocia seu capital com quem oferece melhor preço no mercado.

Este é um ambiente muito propício para a escalada pentecostal aos postos eletivos do estado. Isto porque conseguiram implementar no Brasil uma complexa rede social, justamente motivada numa relação de confiança interpessoal, que, embora centrada na pessoa que empreende esta escalada, a transcende em prol daquilo que justamente atribui identidade ao grupo: Deus. O voto de orientação pentecostal, embora de natureza interpessoal, não se baseia numa relação entre indivíduos, mas na relação que votante e votado mantém com a divindade. A legitimidade da pertença inclui a certeza de um comportamento ético e da defesa de valores comuns. Os pentecostais brasileiros conseguiram o que muitos partidos jamais sonharam: o estabelecimento de uma relação orgânica com sua base social. Seria como se todo o trabalhador brasileiro acreditasse que todo o membro do partido de sua classe lhe representasse legitimamente, porque defensor de valores que a priori lhes são comuns.

Evidentemente que não passam incólumes os choques entre os empreendedores religiosos da política e os bosses. Existe uma sensível diferença entre a relação de Marcello Crivella com a IURD e Garotinho com a Igreja Presbiteriana. Crivella é um bispo profissional que se lança na política. Garotinho é um político profissional com fé declarada e reivindicação de pertença a determinada denominação pentecostal. O que há de comum a ambos é a mobilização política de 
capital identitário. O antigo lema de inspiração progressista "trabalhador vota em trabalhador" esqueceu de lançar nas entrelinhas todo um capital simbólico que se agrega a uma pretensa identidade de trabalhador. É justamente donde vem a legitimação do voto de orientação evangélica, onde "irmão vota em irmão".

A colonização do espaço público se torna possível na medida em que se faz baseada nesta relação de confiança interpessoal, ou, no caso em tela, na certeza de uma legítima representação política do divino. Moldar a terra - o espaço público, portanto - de acordo com os desígnios dos textos sagrados, colonizar todos os espaços com seus signos e sistemas de valores, ainda que em detrimento de uma neutralidade cidadã de inspiração liberal - portanto, laica - se torna possível por esta relação de legitimidade reconhecida pelo grupo.

Não há outro grupo que se possa sobrepor ao grau de organicidade das redes evangélicas. Os homossexuais não possuem base social suficientemente grande para fazer frente de forma organizada às "clínicas de recuperação". A comunidade científica tampouco possui força suficiente para impedir o ensino do criacionismo nas escolas públicas do Estado do Rio de Janeiro. O que impede a formação de esmagadoras maiorias políticas na institucionalidade do estado são dois elementos. $O$ primeiro, instrumental, consiste nos mecanismos parlamentares de produção legislativa, os quais facilitam a vitória de bases imobilistas de caráter reativo, simplesmente impedindo a consolidação da maioria. Outro, ideológico, é justamente a reivindicação de uma cidadania universalizante para o espaço público, em resistência às políticas afirmativas que, por representarem apenas o setor organizado, teriam uma natureza autoritária. Não por outro motivo que o uso do véu foi recentemente banido nas escolas públicas da França, gerando uma inesperada mobilização pública em prol da manifestação da identidade mulçumana no espaço público.

É próprio do discurso da cidadania universal a angustiante ambivalência de representar ao mesmo tempo todos e ninguém.

\section{EVANGÉLICOS NO BRASIL E A TRAJETÓRIA DA “MARCA" GAROTINHO}

Segundo as estatísticas do último censo nacional realizado em 2000, houve um crescimento substancial do número de evangélicos no Brasil. 


\section{Distribuição da população brasileira segundo religiões (1980/2000)}

\begin{tabular}{|l|c|c|c|}
\hline Religião & $\begin{array}{c}1980 \\
(\%)\end{array}$ & $\begin{array}{c}2000 \\
(\%)\end{array}$ & $\begin{array}{c}\text { Variação do N absoluto } \\
1980 / 2000(\%)\end{array}$ \\
\hline Católica & 88.9 & 73.8 & 18.1 \\
\hline Evangélica não-pentecostal & 3.4 & 4.2 & 78.0 \\
\hline Evangélica pentecostal & 3.2 & 10.4 & 357.9 \\
\hline Kardecistas & 0.7 & 1.4 & 171.9 \\
\hline Afro-brasileiras & 0.6 & 0.3 & -15.8 \\
\hline Outras & 1.2 & 1.6 & 79.7 \\
\hline Sem religião & 1.6 & 7.3 & 531.3 \\
\hline Sem declaração & 0.2 & 0.2 & 27.6 \\
\hline Total & 100 & 100 & -- \\
\hline População total do Brasil $(\mathrm{N})$ & 119.011 .052 & 169.411 .759 & 42.3 \\
\hline
\end{tabular}

Fontes: IBGE (2000), IBGE (1982).

Segundo Katia Mika Nishimura [2005], os pentecostais se auto-excluíram da vida pública até os anos 80 . Durante a ditadura, no entanto, os governos militares, privados do apoio dos católicos estabeleceram alianças com diversos líderes evangélicos (protestantes e pentecostais), porque muitos eram anticomunistas e de fácil cooptação clientelista, para conseguirem recursos e reconhecimento social e político. Mesmo assim, os pentecostais permaneciam se auto-excluindo da vida pública. Todavia, ainda na década de 1980, houve uma inversão da crença segundo a qual "crente não se mete em política" para o jargão corporativo "irmão vota em irmão", que deu origem ao novo campo de inserção social das igrejas pentecostais. Todavia, as denominações "Congregação Cristã no Brasil" e "Deus é Amor", duas das maiores igrejas pentecostais do país, permanecem apolíticas. Desde então, a filiação desses religiosos a partidos de centro-esquerda vem aumentando, especialmente aqueles vinculados a novas igrejas, ou melhor, às chamadas neopentecostais, como Universal do Reino de Deus (IURD) e a Assembléia de Deus, que assumiu o protagonismo político no campo evangélico. No campo das eleições majoritárias, além de procurarem eleger candidatos próprios, como Francisco Rossi, Benedita da Silva, Marcelo Crivella, Anthony e Rosinha Garotinho, os pentecostais e

\footnotetext{
${ }^{2}$ Quadro retirado do artigo de Simone R. Bohn.
} 
neopentecostais ${ }^{3}$ mobilizam seu eleitorado classificando os candidatos como sendo apoiados por eles ou por outras religiões. Em 1989, no segundo turno entre Collor e Lula, os pentecostais condenaram o voto em Lula porque diziam temer a perda de sua liberdade religiosa num futuro governo comunista aliado à filial brasileira da Santa Sé. Nas eleições presidenciais de 1994, Lula foi o mais rejeitado por esse grupo religioso, que apoiou Fernando Henrique. Em 2002, com a derrota de Garotinho no primeiro turno, líderes da Universal do Reino de Deus (e de outras igrejas pentecostais) resolveram apoiar a candidatura de Lula no segundo turno das eleições presidenciais, em função da coligação com o PL para candidatura à VicePresidência de José Alencar.

Os deputados e senadores pentecostais dedicam-se à defesa intransigente de seus interesses corporativos e de uma moralidade cristã estrita, relacionadas, por exemplo, às políticas públicas e debates legislativos sobre a descriminalização do aborto e do consumo de drogas, à união civil de homossexuais, aos direitos humanos e sexuais, às tecnologias reprodutivas, à clonagem humana, ao uso de células embrionárias em pesquisas científicas, ao ensino religioso nas escolas públicas e à reforma política.

O exemplo caricatural, todavia, é o do casal Garotinho no Estado do Rio de Janeiro. Não é possível falar da trajetória de Rosinha Matheus na política sem apresentar a trajetória de seu marido, Anthony Garotinho, especialmente porque Rosinha não tem um passado político. Como diz o próprio Garotinho em seu site "Garotinho fé no Brasil":

...quando deixei o governo do Estado para me candidatar a presidente da República, em 2001, essa aprovação era tão alta que a Rosinha foi eleita no primeiro turno!

[...] No Rio, além de ter sido o candidato a presidente mais bem votado, Garotinho teve outra mostra de que o eleitorado fluminense o aprovava: por 4.101 .423 (51,30\% dos votos válidos), mais do que o dobro da candidata do PT, Benedita da Silva, Rosinha Garotinho foi

\footnotetext{
${ }^{3}$ Esta é uma classificação utilizada por Emerson Giumbelli [2001], embora existam críticas em relação a esta tipologia que compreende os pentecostais clássicos", "pentecostais neoclássicos" e "neopentecostais", por se referir a critérios teológicos, ou seja, que rompem com a neutralidade típico-ideal. Inobstante isto ela ajuda a compreender a ligação com a cura, o exorcismo e a prosperidade, que a caracteriza, inserindo neste contexto a IURD.
} 
eleita governadora no primeiro turno. Pela primeira vez, desde a fusão dos estados do Rio de Janeiro e da Guanabara, em 1975, um governador do Rio fez o sucessor. ${ }^{4}$

Rosinha conheceu Garotinho em um grupo de teatro, do qual ambos participavam. Casada a 22 anos com Garotinho, é formada no curso normal pelo Colégio Batista Fluminense, foi radialista, presidente da ONG "Vida Obra Social" e secretária de Estado de Ação Social e Cidadania, durante a gestão do marido. Foi eleita governadora do Rio de Janeiro devido ao carisma que Garotinho conquistou no Estado com o discurso religioso. Poderíamos dizer que hoje existe uma "marca" Garotinho, que é a imagem do casal. Essa imagem é muito bem apresentada no site "Garotinho fé no Brasil”. Neste site, podemos encontrar depoimentos de pastores da Igreja Presbiteriana do Brasil sobre a imagem que o casal tem na igreja, bem como a importância desta representação, segundo esses fiéis, para a política.

Anthony Garotinho, por outro lado, em 1982, com 22 anos foi candidato a vereador da cidade de Campos (RJ), mas não conseguiu se eleger. Em 1983, filiouse ao PDT e, em 1986, elegeu-se deputado estadual do Estado do Rio de Janeiro. Em 1988, foi eleito prefeito de Campos com a campanha "Tostão contra Milhão". Em 1993, foi convidado pelo governador Leonel Brizola a assumir a Secretaria de Estado de Agricultura, Abastecimento e Pesca. Em 1994, candidatou-se a Governador do Estado do Rio de Janeiro, perdeu por 4\% dos votos para Marcello Alencar. Durante essa campanha, Garotinho sofreu um acidente de carro, que dificultou a campanha, mas como ele próprio diz, "o acidente foi uma graça de Deus", que lhe trouxe a verdadeira vitória: "a conversão para Jesus"5. Em 1996, Garotinho foi novamente eleito prefeito de Campos, no primeiro turno, com $74 \%$ dos votos válidos, derrotando cinco candidatos. Mas deixou a Prefeitura, em 1998, para ser candidato ao Governo do Rio de Janeiro. Em 2000, candidatou-se pelo PSB à Presidência da República, na sua primeira disputa nacional obteve 15.179 .879 votos (17,87\% dos votos válidos), ficando em terceiro lugar no primeiro turno das eleições presidenciais. Hoje é presidente estadual do PMDB do Estado do Rio de Janeiro.

\footnotetext{
${ }^{4}$ Disponível em: http://www.orepelobrasil.com.br/. Consulta em 12 de junho de 2005.
}

${ }^{5}$ Diz o site: "Isto porque foi durante o tempo em que esteve internado que recebeu a visita de um servo de Deus que lhe pregou o Evangelho e orou com ele num momento de angústia. No livro 'Virou o carro, virou a minha vida1' (Agência Soma, 2001, 6⿳亠丷厂 edição), Garotinho compartilha sua experiência de conversão com a intenção de que aqueles que ainda não conhecem a Jesus, através deste testemunho também tenham suas vidas transformadas pelo poder do Espírito Santo." 
Desde a "conversão" de Garotinho, sua imagem pública tem sido projetada a partir de sua identidade religiosa. O site "Garotinho fé no Brasil" constrói uma imagem de homem público que tornou-se melhor, que prosperou na família e na política depois da conversão à religião. Além disso, o site também procura justificar a empreitada política através da pregação da visão religiosa evangélica bastante particular, dizendo que: "Faz parte da minha missão espalhar a Palavra do Senhor e mostrar como Jesus pode transformar a vida de cada pessoa, assim como transformou a minha vida", a respeito das críticas que recebe na vida política, por citar em seus discursos e entrevistas trechos da bíblia.

Neste site, no ícone igreja, há algumas declarações de pastores da Igreja Presbiteriana em apoio às recentes candidaturas do casal, à Presidência e Governo do Estado. São declarações que procuram legitimar a representação política que o casal exerce, como sendo manifestação do divino, porque eles são "irmãos" da igreja, portanto, comungam do mesmo deus. Declarações que explicitamente procuram mobilizar capital eleitoral para o casal.

Além desse espaço nas igrejas, Garotinho apresenta programas religiosos na Rede TV e na Bandeirantes, e vários programas de rádio de alguns estados, especialmente Bahia, Rio de Janeiro e São Paulo.

Algumas manifestações públicas de Garotinho sobre o homossexualismo foram bastante veiculadas pela mídia. Um delas, em 2001, quando Garotinho deu entrevista na TV Gazeta dizendo ser contra o homossexualismo. Todavia, devido à represálias que sofreu de movimentos gays, expediu um decreto para regulamentar a lei $n^{\circ} 3.406$, de 15 de maio de 2000, que pune a discriminação por "orientação sexual.

$\mathrm{Na}$ época das eleições para Presidência, no entanto, Garotinho novamente disse ser contra o homossexualismo, valendo-se de um trecho da bíblia de sua igreja:

Eu sou contra (o homossexualismo) porque eu não gostaria para os outros, o que não desejaria para mim. Uma coisa é o homossexualismo, outra coisa é o homossexual. Uma coisa é o pecador, outra é o pecado. Sou contra o homossexualismo. Abertamente contra. Algumas pessoas exercem (o homossexualismo) até de uma forma tão elegante que eu admiro. 
Tentando melhorar a imagem do marido, Rosinha, por sua vez, reiterou a opinião do marido:

Ele apenas não concorda com a prática do homossexualismo, mas não tem nada contra as pessoas que praticam 0 ato. Temos amigos homossexuais, mas temos 0 direito de não concordar com essa prática. ${ }^{6}$

Já como governadora, Rosinha vetou o parágrafo $7^{0}$ da lei nํ4 4320/2004, que concedia pensão em caso de morte aos parceiros de servidores públicos homossexuais.

Como vemos, a conversão de homossexuais para a heterossexualidade tem sido uma proposta bastante defendida pelos evangélicos. O grupo MOSES (Movimento pela Sexualidade Sadia) é mais uma evidência da prática religiosa fundamentalista que procura por todos os meios concretizar os seus desígnios. No site $^{7}$ deste movimento, encontramos os fundamentos bíblicos que os evangélicos neopentecostais oferecem como justificativa para a homofobia, bem como teses psiquiátricas sobre a possibilidade de "conversão" dos homossexuais. O movimento surgiu na cidade do Rio de Janeiro, a partir da iniciativa de três pessoas: João Luiz Santolin e Liane França, da Igreja Presbiteriana da Barra da Tijuca e Sérgio Viula, da Igreja Batista da Penha Circula, mas atende a todo o Brasil, por telefone ou apresentando palestras.

Ligado ao grupo MOSES, o MEP (Movimento Evangélico Progressista) que compõe uma Frente Parlamentar no Congresso com 60 deputados federais e 3 senadores, tem como um de seus objetivos combater o homossexualismo, o aborto, entre outros temas. No Estado do Espírito Santo, o deputado, Neucimar Fraga (PL/ES), fiel da Igreja Batista e membro do MEP, entrou com o projeto-de-lei para reorientação sexual, que foi rejeitado. O presidente do MOSES, João Luiz Santolin, quando o projeto foi rejeitado, disse que "o dinheiro público deveria ser gasto para combater um comportamento que não é natural"8.

No Estado do Rio de Janeiro, o deputado Edino Fonseca (PSB/RJ), pastor da Assembléia de Deus, apresentou o projeto-de-lei $n^{\circ} 717 / 2003$, a fim de criar um

6 Disponível em: http://www2.uol.com.br/diariodovale/arquivo/2001/novembro/10/page/frcidade.htm, consulta em 12 de junho de 2005.

${ }^{7}$ Disponível em: www.moses.org.br, consulta em 12 de junho de 2005. 
programa estadual de auxílio a pessoas que voluntariamente optassem pela mudança da homossexualidade para a heterossexualidade. O dinheiro público seria orçado em favor de "organizações governamentais, não governamentais, Associações Civis, religiosas, profissionais liberais e autônomos” (art. 1, par. único), que tivessem interesse em trabalhar a conversão, além de servir para custear "programas de coletas e divulgação de informações junto a organizações governamentais e não governamentais, sobre a prevenção, apoio e/ou possibilidade de reorientação sexual das pessoas que vivenciam a homossexualidade que assim desejarem, bem como das crianças e adolescentes sob a responsabilidade dos seus pais, guardião ou tutor" (art. 29. Mas o projeto t ambém foi rejeitado, por trinta votos contra seis.

Se a interseção da religião no espaço público ainda não se materializou quanto à conversão de homossexuais, o mesmo não se pode dizer quanto à adoção do criacionismo como disciplina curricular obrigatória em todas as escolas estaduais de ensino fundamental e médio do Rio de Janeiro.

O governo estadual de Rosinha Matheus regulamentou a previsão da lei no 3.459/2000, fazendo concursos para professores de religião, que já estão lecionando. Segundo informações da Secretaria de Educação do Estado, a matrícula é facultativa nos termos da lei, todavia, por decisão do governo do Estado, deve ser feita pelos pais ou tutores de crianças e adolescentes até os 16 anos. Uma vez inscrito, somente os pais podem solicitar o cancelamento da matrícula. Segundo servidora do Estado, Suzana, "o ensino é confessional, mas não objetiva catequizar ou evangelizar, mas tratar de temas relacionados à vida segundo os fundamentos das religiões". As autoridades religiosas é quem fazem o programa da disciplina e orientam os professores, todavia, o professor não é obrigado a seguílas, podendo construir um método e visão próprios. Os professores se reúnem periodicamente para trocar experiências. A priori, deveria haver professores de todas as religiões, mas o concurso de 2004 abriu 500 vagas, sendo 342 reservadas para católicos, 132 para evangélicos e 26 para outras religiões. Os 500 professores não atendem toda a demanda que é de 1600 professores. junho de 2005.

8 Disponível em: http://www.aids.gov.br/imprensa/Noticias.asp?NOTCod=62067. Consulta em 12 de 
A lei $n^{\circ} 3.459 / 2000$ partiu de projeto do ex-deputad o católico Carlos Dias (PP/RJ), no então governo de Anthony Garotinho. Em reação a este projeto, o deputado estadual Carlos Minc (PT/RJ) propôs projeto que alterava a lei de autoria do ex-deputado Carlos Dias. O projeto Carlos Minc previa que as aulas de religião, de caráter facultativo, fossem ministradas do ponto de vista histórico-antropológico. O plenário da Assembléia Legislativa do Estado do Rio de Janeiro (Alerj) aprovou o projeto-de-lei, em 16 de outubro de 2003, que no entanto, foi vetado pela governadora Rosinha Garotinho.

Em entrevista à revista ComCiência, o ex-deputado Carlos Dias, expressa claramente o senso comum do criacionismo:

“ComCiência - Não há risco do ensino das teorias evolucionista e criacionista nas escolas confundir os alunos?

Dias - Os alunos vão aprender que existe a teoria do evolucionismo e nós vamos ouvi-la, assim como somos instruídos sobre a Segunda Guerra Mundial e sobre uma série de outros fatos que fazem parte do conhecimento humano. Isso não quer dizer que [a biologia] seja uma matéria absolutamente verdadeira, no sentido que você tem que tomar aquilo como posse, sair divulgando e achar que essa é a verdade. É simplesmente uma matéria que pode ser estudada. Estudar as condições que levaram Darwin a pensar no evolucionismo, quais são exatamente as origens desse pensamento. Acho muito positivo que se ensine isso. Agora, ninguém vai chegar em uma criança e dizer "sua origem humana veio da evolução do macaco". Não há como colocar isso de uma maneira que as crianças tenham que aceitar. Acho que ninguém aceita isso. Mas isso também não quer dizer que não se possa ensinar essa teoria.

ComCiência - Então o senhor acha que é possível harmonizar ciência e fé?

Dias - Ciência e fé sempre andaram juntas. Louis Pasteur já dizia isso: "Pouca ciência afasta de Deus; muita, aproxima". Não há nenhuma incompatibilidade entre ciência e fé. A ciência é uma grande possibilidade de Deus, que, iluminando nossa racionalidade, nos dá condição de enfrentar os desafios da própria natureza humana. O tratamento de doenças, as possibilidades de melhoria das condições de saneamento, de qualidade de vida, isso tudo é resultado de uma iluminação profunda na mente humana pela graça de Deus. A ciência sem a fé não avança". ${ }^{9}$

${ }^{9}$ Disponível em: http://www.comciencia.br/200407/entrevistas/entrevista2.htm. Consulta em: 12 de junho de 2005. 
Todavia, o criacionsimo é uma corrente científica que vem crescendo tanto nos EUA quanto no Brasil. Uma pesquisa feita pelo lbope a pedido da revista "Época", diz que 31\% dos brasileiros acreditam que Deus criou o ser humano como somos hoje nos últimos 10 mil anos (nos EUA 55\%); 54\% acreditam que o ser humano vem se desenvolvendo ao longo de milhões de anos, mas sob a direção e intervenção de Deus; e 75\% crêem que o criacionismo deve substituir a evolução no currículo escolar.

\section{CRIACIONISMO E CONVERSÃO: DO ASCETISMO LAICO AO ESTOICISMO RELIGIOSO (OU SOBRE A ECONOMIA REALIZADA NA CONVERSÃO DE CAPITAL RELIGIOSO EM CAPITAL POLÍTICO)}

A este ponto nos é imperiosa uma análise do impacto político do discurso religioso nas multidões, no contexto da realidade histórica e das condições econômicas hoje observadas no Estado do Rio de Janeiro. O que indagar de nosso objeto para que ele revele o que buscamos? Evidentemente sobre quais foram as reinterpretações por que passou o pensamento protestante diante do atrito com a realidade social encontrada.

O protestantismo se constituiu como força motriz de transformações sociais baseado na notícia da incerteza da salvação. Não mais bastava a participação litúrgica e a autoproclamação confessional para que uma alma fosse "salva". Era necessário o exercício constante e permanente da vocação. Conceito de inspiração Luterana, por vocação devemos entender os sinais perceptíveis nas pessoas de uma vida segundo as leis divinas. Ao contrário do que comumente se expressa, o ascetismo laico não tinha condições materiais de expressão de forma absolutamente falseada. Não se devem entender os tais sinais como simplesmente 0 comportamento cortês, contido, reprimido e disciplinado.

Isto porque - e não traço exclusivo do protestantismo - é no trabalho que se verifica de forma definitiva uma vida dedicada á obra de Deus. Parafraseando São Paulo: "quem não trabalha não deve comer". A prática do ócio era o traço fundamental do desvio vocacional. A inovação deste traço fundamental, percebida a partir da difusão da ética protestante, consiste na sua reinterpretação para elevar o valor trabalho ao de trabalho produtivo. Ulteriormente, a vocação em Lutero é 
percebida então não pela constante atividade laborativa, mas dos frutos do trabalho [WEBER. 2004. pp. 146]. Desta forma a prosperidade material - o que o catolicismo mantinha como promessa apenas na outra vida - é elevada no protestantismo à categoria de sinal de graça. A vocação para a salvação consiste nas bênçãos derramadas sobre aqueles que estão trabalhando sob as leis de Deus, o que significa muito mais que um conjunto de signos e comportamentos, mas de resultados verificáveis pelos olhares mais pragmáticos.

A promessa constante das diversas denominações pentecostais hoje em atividade no Brasil é também a prosperidade em vida, o que se pode obter não pela conversão, mas à partir dela. É comum vermos nos programas televisivos de inspiração evangélica depoimentos de vidas transformadas pela conversão. Uma mulher, abraçada ao marido, conta detalhadamente as inúmeras vezes que, em seus tempos de desvio, adulterou. Não se percebe qualquer sinal de constrangimento no casal, mas, ao contrário, até uma certa alegria e desprendimento. Isto porque os depoentes não falam de si mesmos, mas de outra pessoa. A conversão possibilita o nascimento de um alter ego, ou, no dizer corrente das igrejas, a "nova criatura".

Os atritos começam a ser sentidos quando se percebe que o prefixo "ex" não é traço fundamental da vocação. O novo ego não se resigna simplesmente na autocrítica de práticas atribuídas ao "demônio", como o uso de drogas, o adultério, o ócio e o homossexualismo. É necessária a prova material da chegada da bênção: a prosperidade.

Conforme já vimos anteriormente, e na descrição de outro contexto histórico, a pertença a uma denominação religiosa agrega à pessoa valores absolutamente laicos como o acesso ao crédito, ou à clientela. No contexto do Estado do Rio de Janeiro dos dias atuais a situação é outra. Não é por acaso que a (oni)presença satânica é alardeada nas igrejas evangélicas hodiernamente. O contexto de desemprego, injustiça social, violência e pobreza - mormente em áreas de maior votação de Rosinha e Anthony Garotinho, como a Baixada Fluminense e o interior do Estado - força uma experiência cognitiva generalizada de resposta imediata a tais estímulos. É o diagnóstico de Bellar para a fase moderna das religiões nos países de capitalismo tardio [pp. 265-6]. Dividindo a religiosidade em cinco fases primitiva, arcaica, histórica, pré-moderna e moderna - o autor assevera que, no 
nosso dado contexto, há profusão de "visões de mundo claras e simples e um imperativo imediato para a ação" [pp. 266]. Não é vendável a mercadoria da prosperidade neste contexto. É necessária, conjuntamente com o capital identitário, a mobilização de referências simbólicas e psicológicas.

Para Maurício Martins, é a ausência de projetos políticos eficazes que abre espaço para a profusão de políticas institucionais que levem ao espaço público a interpretação rígida do texto sagrado [op. cit.], fornecendo aos pressupostos clientes muito mais que a oportunidade da conversão e do abandono do ego, mas um rígido sistema de referências onde o caos imposto pelo contexto é substituído pela ordem dos desígnios providenciais. Faz numa crítica justamente ao ensino do criacionismo nas escolas públicas do Estado, que, segundo o projeto da Governadora, será ministrado como alternativa à concepção darwinista da evolução das espécies.

Portanto, as políticas públicas a que atribuímos 0 caráter de "evangelizadoras", notadamente o ensino criacionista nas escolas públicas e a criação de instituições para "tratamento" de homossexuais, de fato visam cumprir um papel mais abrangente que o aumento de conversões, fiéis e dízimos, é mais que um caminho para a salvação trilhado no espaço público. É o corolário de uma reinterpretação da vocação, que pode ser compreendida como um movimento regressivo, onde os frutos do trabalho são relevados mediante a prática cotidiana fundamentalista das regras sagradas para a vida material. $O$ alter que se presume morto na conversão à "nova criatura" revela sua vocação na autoproclamação do que, justamente, deixou de ser. Uma nova identidade é a mercadoria do momento. $E$ sim, é a ausência de projetos políticos promissores da ultimada prosperidade material que abrem espaço para o discurso de legitimidade de políticas públicas impositivas de uma visão de mundo particular e de inspiração confessional. Uma visão de mundo que, segundo seus padrões de efetividade, garante a todos o exercício da cidadania.

Ainda Weber nos fornece a chave para a formulação de hipóteses neste campo, na análise universal da vocação como categoria de compreensão das religiões universais [1992b, pp. 254-5]. Uma religião onde os bens de salvação apenas são alcançáveis por poucos - no dizer do autor, uma "religião de virtuosos" ao longo da história ostentou contra si, de tempos em tempos, a revolta da massa, posta como "objeto" da religião mediante uma rígida monopolização e regulação 
oficiais dos bens de salvação. Os ministros destas religiões, organizados enquanto privilegiados políticos à moda da aristocracia estamental, eram os verdadeiros "sujeitos" da religião.

Sejam os brâmanes do hinduísmo, os monges peregrinos do confucionismo, os guerreiros predestinados fundadores do islã, fato é que o acesso ao espaço privilegiado ao divino (seja pelo alcance do "nirvana", da "walhalla" de um estado contemplativo, orgástico de caráter não-terreno..) os bens de salvação não estão comumente disponíveis á todos mediante o adestramento do ethos. Para Weber, o decisivo no estudo sociológico da religião, são as reinterpretações dos textos sagrados no sentido de oferecer concessões "democratizantes" dos bens de salvação, diante, principalmente, de formas religiosas populares insurgentes que ameaçam sua hegemonia. Geralmente estas concessões são produtoras de uma ética cotidiana racional que, por um baixo custo, pode ser praticada por todos.

A identidade evangélica, portanto, iguala pastores e fiéis, seja no aspecto cotidiano, seja no de representação da relação com a divindade. Sua diferença é questão de simples especialização funcional. Estão eqüidistantes da salvação mediante uma mesma prática cotidiana. Louvor e abstinência como valores orientadores da ação cotidiana e molde identitário garantem o ingresso no "reino dos céus". Por outro aspecto, esta homogeneização é a pedra-de-toque dos laços organizacionais das redes evangélicas, bem como do processo de laicização de seus aspectos religiosos. Fazer negócios, votar, relacionar-se no espaço público requer uma confiança que a desagregação de nosso tempo só permite em espaços (ou, entre indivíduos) onde se previamente negocia o status de igualdade entre os membros.

\section{CONCLUSÃO}

Assim, desta exposição não se pode deixar de explicitar a imbricação recíproca entre cidadania e identidade. Cabe uma ressalva metodológica nesta conclusão para que não se incorra em equívocos, a trama de relações sociais é extremamente complexificada e, portanto, utilizou-se duas ferramentas teóricas para compreender cursos de ação que culminaram na pretensão de instituir as políticas públicas em discussão, isto não quer dizer que as causas exclusivas deste fato 
decorram da presença de uma Governadora evangélica, mas que sua passagem pelo poder fomentou este fenômeno.

Aliás, o que se pode depreender é que, pelo fato de pertencer a um grupo religioso minoritário - aqui está a se referir aos evangélicos globalmente -, que proveu as condições para guindá-la o poder político, permitiu a exposição pública do ethos por meio de tais políticas. O exercício da cidadania, ou a demanda por prestações estatais, se vincula ao modo de perceber o mundo do indivíduo, isto é, com suas relações materiais e imateriais com a realidade em que vive. A demanda concreta, no caso em tela, não se desvincula da cosmologia construída pelos evangélicos.

A hipótese vestibular deste trabalho de legitimação da autoridade religiosa no espaço público, infelizmente, não pode ser demonstrada aqui, já que os limites deste impedem tal tomada de posição, uma vez que seria necessário empregar uma metodologia de uma pesquisa de maior fôlego para tal corroboração. Todavia, estas poucas linhas permitem concluir que o espaço público está sendo assediado por fundamentações que Ihes são estranhas, em função da separação entre Estado e igreja, a confissão religiosa e suas motivações foram postas para fora do espaço público. Ora, não se tem uma visão normativa da realidade, já que as relações entre política e religião nunca se desfizeram completamente, mas o que há de curioso é que a motivação é explicitamente religiosa. A "conversão" de homossexuais e o ensino do criacionismo não se fundamentam em critérios públicos e científicos passíveis de revisão, ao contrário expõem uma visão de mundo própria de um grupo. Assim, quando a relação é sub-reptícia, a exposição de motivos não é escancaradamente religiosa, mas ocorre com arrazoados não-religiosos.

O que parece - e não pretendemos ser contra ou a favor dos evangélicos com esta afirmação - é que esta relação notoriamente perceptível revela uma ambigüidade sempre presente na política brasileira, a dificuldade de se perceber o espaço público como factualmente universal. O paradoxo do espaço público universalista desaparece neste contexto, já que as demandas atendem à expectativas de um grupo homogêneo. $O$ ponto positivo disto é a assunção de direito e de fato de uma esfera fragmentada com sujeitos interessados, ou seja, os governantes deixam de esconder suas ações atrás do véu retórico do bem do povo. Não se quer dizer que esta prática deixou de existir, porém que os fatos permitem 
inferir que as ações governamentais atendem a demandas peculiares dos grupos emergentes. A fragmentação é um sintoma do pluralismo manifestante, mas também a indicação de um espaço público composto de sujeitos interessados com demandas e necessidades específicas, de tal modo que os embates entre tais interesses é que pautaram os rumos. Deixa-se, pois, de ser percebido como um ambiente harmônico, no qual o bem de todos é o escopo público das ações, onde o consenso impera como pressuposto delas.

\section{REFERÊNCIAS BIBLIOGRÁFICAS}

ARENDT, Hannah. A condição humana. 10. ed. trad. Roberto Raposo. Rio de Janeiro: Forense Universitária, 2004.

BELLAH, Robert N. A Sociologia da Religião. In PARSONS, Talcott (Org.). "A Sociologia Americana". São Paulo: Cultrix, 1970.

BOHN, Simone R. Evangélicos no Brasil: perfil socioeconômico, afinidades ideológicas e determinantes do comportamento eleitoral. Opin. Publica, out. 2004, v.10, n.2, p.288-338.

BRANDÃO, Carlos Rodrigues. Ser católico: dimensões brasileiras - um estudo sobre a atribuição de identidade através da religião. In: SACHS, Viola et alli. Brasil \& EUA: religião e identidade nacional. Rio de Janeiro: Graal, 1988.

CARVALHO, José Murilo de. Cidadania no Brasil. O longo caminho. Rio de Janeiro: Civilização Brasileira, 2004.

CARVAlHo, Maria Alice Rezende de. Cultura Política, Capital Social e a Questão do Déficit Democrático no Brasil. In VIANNA, Luiz Werneck (Org.). "A Democracia e os Três Poderes no Brasil". Rio de Janeiro: IUPERJIFAPERJ, Belo Horizonte: Editora UFMG, 2002.

GIUMBELLI, Emerson. A vontade do saber: terminologias e classificações sobre o protestantismo brasileiro. In: "Religião e sociedade". v. 21. n. 1 Rio de Janeiro: ISER, 2001.

MARTINS, Maurício Vieira. O Criacionismo Chega às Escolas do Rio de Janeiro: uma abordagem sociológica. In Revista ComCiência n 56, 2004. Consulta em: 17 de maio de 2005. Disponível em: www.comciencia.br/200407/reportagens/10.shtml.

NISHIMURA, Katia Mika Conservadorismo social: opiniões e atitudes no contexto da eleição de 2002. In Revista ComCiência 56, 2004. Consulta em 08 de junho de 2005. Disponível em: http://www.comciencia.br/reportagens/2005/05/13.shtml.

WEBER, Max. Las Sectas Protestantes y el Espíritu del Capitalismo. In "Ensayos Sobre Sociología de la Religión". Madrid: Taurus Humanidades, 1992a, v. I. 
Introducción a La Ética Económica de las Religiones Universales. Ensayos de Sociología Comparada de la Religión. In "Ensayos Sobre Sociología de la Religión". Madrid: Taurus Humanidades, 1992b, v. I.

Economía y Sociedad. México, DF: Fondo de Cultura Económica, 1999.

A Ética Protestante e o Espírito do Capitalismo. Trad. José Marcos Mariani Macedo. 2. reimp. São Paulo: Companhia das Letras, 2004. 